\title{
Two new species of forget-me-nots (Myosotis, Boraginaceae) from New Zealand
}

\author{
Carlos A. Lehnebach' \\ I Museum of New Zealand Te Papa Tongarewa, POBOX 467, Wellington, New Zealand \\ Corresponding author: Carlos A. Lehnebach (CarlosL@tepapa.govt.nz)
}

Academic editor: James Miller | Received 27 June 2012 | Accepted 13 August 2012 | Published 21 August 2012

Citation: Lehnebach CA (2012) Two new species of forget-me-nots (Myosotis, Boraginaceae) from New Zealand. PhytoKeys 16: 53-64. doi: 10.3897/phytokeys.16.3602

\begin{abstract}
Two new species of forget-me-nots, Myosotis chaffeyorum C.A.Lehnebach sp. nov. and Myosotis mooreana C.A.Lehnebach sp. nov. are described and illustrated. These species are endemic to New Zealand and restricted to the mountains of north-west Nelson (South Island). Both species are uncommon and $M$. mooreana is known from the type locality only. Their conservation status is rated as "Nationally Critical". A table listing differences between these two new species and other similar species and an identification key are provided.
\end{abstract}

\section{Keywords}

Boraginaceae, Kahurangi National Park, Myosotis, Myosotis chaffeyorum, Myosotis mooreana, new species, New Zealand, New Zealand Flora

\section{Introduction}

The genus Myosotis L. is found in the Northern and Southern Hemisphere. Phylogenetic analyses of nuclear and chloroplast sequences suggest Myosotis originated in the Northern Hemisphere (Winkworth et al. 2002) and is nested within the tribe Cynoglosseae along with Trigonotis Steven (Weigend et al. 2010). In the Southern Hemisphere, New Zealand is the centre of diversity for the genus Myosotis, and 39 species have been listed for the country (Breitwieser et al. 2012). These species occupy a great diversity of habitats ranging from coastal cliff faces and sand dunes to stream banks in

Copyright Carlos A. Lehnebach. This is an open access article distributed under the terms of the Creative Commons Attribution License 3.0 (CC-BY), which permits unrestricted use, distribution, and reproduction in any medium, provided the original author and source are credited. 
forests, tussock grasslands, tarns, limestone and marble outcrops, and scree-slopes on the mountains of the Southern Alps. This ecological diversification is matched by an equally remarkable diversification of habit (cushion, single rosette, creeping/trailing stems), plant size (less than a centimetre to up to $40 \mathrm{~cm}$ height), and vegetative (leaf shape, indumentum type) and reproductive characters (white, yellow, brown-bronze, blue flowers and automatic selfing and out-crossing species).

Despite the many phenotypic differences exhibited by New Zealand Myosotis, identification at the species level can be challenging, especially when dealing with rare or under-collected species or poorly press-dried specimens in which flower and leaf characters have become distorted. The former situation, in particular, is commonly encountered by students of this genus, as many species have a highly restricted distribution with small-size populations (Brandon 2001). In fact, some of the currently recognised species are known only from a single locality (e.g. M. alboserica Hook.f., $M$. laeta Cheeseman) or, in more extreme cases, the type collection is the only collection ever made (e.g. M. laingii Cheeseman).

Currently, a revision of the genus Myosotis in New Zealand is underway and species limits for a number of widespread and critically endangered species are under assessment. Also, phylogenetic affinities within New Zealand species are being studied using DNA sequences of both nuclear and chloroplast markers and AFLP fingerprinting data (Meudt et al. in preparation). Towards this end, a number of collecting trips to sub-alpine and alpine areas of the North and South Island of New Zealand have taken place between 2009 and 2012. An expedition to Kahurangi National Park in north-west Nelson (South Island, 41 ${ }^{\circ} 11^{\prime} 26^{\prime \prime S}, 172^{\circ} 44^{\prime} 52^{\prime \prime E}$ ), one of the diversity hotspots for Myosotis in the country, uncovered the existence of two morphologically and ecologically distinct entities, which are illustrated and described here as new species. An identification key and a table summarising morphological differences between these two new species and other morphologically similar species are included.

\section{Methods}

Specimens were press-dried in the field as soon as they were collected. Flowers, when available, were collected and preserved in $70 \%$ ethanol for later examination. Some samples were kept fresh and later photographed under a dissecting microscope. To test whether phenotypic differences observed in the field were due to phenotypic plasticity, some samples were cultivated for two seasons, under common garden conditions. Vegetative and reproductive characters were observed and measured from fresh and press-dried material. These records were later compared with descriptions in Moore (1961, 1988), Moore and Simpson (1973), and with fresh and dried material of morphologically similar species, i.e. $M$. brockiei L.B.Moore \& M.J.A.Simpson, $M$. forsteri Lehm., M. matthewsii L.B.Moore, and M. spathulata G.Forst. (Table 1). Collections of Myosotis from the Allan Herbarium (CHR), the Department of Conservation Nelson- 
Table I. Morphological comparison of M. chaffeyorum, M. mooreana with other species of Myosotis. Data for M. brockiei, M. forsteri, M. matthewsii, and M. spathulata are from Moore (1961, 1988), Moore and Simpson (1973) and representative voucher specimens (Appendix 1).

\begin{tabular}{|c|c|c|c|c|c|c|}
\hline Character & M. chaffeyorum & M. matthewsii & M. spathulata & M. mooreana & M. brockiei & M. forsteri \\
\hline $\begin{array}{l}\text { Rosette leaf } \\
\text { lamina shape }\end{array}$ & orbicular & orbicular & $\begin{array}{l}\text { orbicular to } \\
\text { broadly elliptic }\end{array}$ & obovate & $\begin{array}{l}\text { narrow- } \\
\text { elliptic }\end{array}$ & $\begin{array}{l}\text { orbicular } \\
\text { to broadly } \\
\text { elliptic } \\
\end{array}$ \\
\hline $\begin{array}{l}\text { Rosette leaf } \\
\text { lamina size } \\
(\mathrm{mm})\end{array}$ & $\begin{array}{l}8.1-8.9 \times 7.7 \\
-9.2\end{array}$ & $\begin{array}{l}16.8-21 \times \\
15.3-20.3\end{array}$ & $\begin{array}{l}10.1-16.3 \times \\
9-12.2\end{array}$ & $\begin{array}{l}32.4-56 \times \\
15.8-20.5\end{array}$ & $\begin{array}{l}60-120 \times \\
10-15\end{array}$ & $\begin{array}{l}25-30 \times \\
31-39\end{array}$ \\
\hline $\begin{array}{l}\text { Leaf } \\
\text { indumentum }\end{array}$ & strigose & hispid & hispid & hispid & tomentose & hispid \\
\hline $\begin{array}{l}\text { Hairs on leaf } \\
\text { margin }\end{array}$ & appressed & appressed & arcuate & $\begin{array}{l}\text { arcuate/ } \\
\text { straight }\end{array}$ & arcuate/erect & arcuate \\
\hline $\begin{array}{l}\text { Rosette leaf } \\
\text { petiole width } \\
(\mathrm{mm})\end{array}$ & $0.2-0.3$ & $0.5-0.6$ & $0.3-0.4$ & $1.4-1.8$ & $1.8-1.9$ & $1.9-3$ \\
\hline $\begin{array}{l}\text { Hairs on } \\
\text { petiole }\end{array}$ & appressed & appressed & erect/arcuate & arcuate & arcuate & $\begin{array}{l}\text { erect/ } \\
\text { arcuate }\end{array}$ \\
\hline Stem habit & decumbent & decumbent & creeping & ascending & erect & ascending \\
\hline Hairs on stem & appressed only & appressed only & erect/arcuate & $\begin{array}{l}\text { appressed, } \\
\text { arcuate, erect }\end{array}$ & $\begin{array}{l}\text { appressed, } \\
\text { arcuate, } \\
\text { erect }\end{array}$ & $\begin{array}{l}\text { arcuate/ } \\
\text { appressed }\end{array}$ \\
\hline $\begin{array}{l}\text { Stem rooting } \\
\text { at nodes }\end{array}$ & no & no & yes & no & no & no \\
\hline $\begin{array}{l}\text { Flower } \\
\text { arrangement }\end{array}$ & $\begin{array}{l}\text { solitary, usually } \\
\text { opposite to leaf }\end{array}$ & $\begin{array}{l}\text { ill-defined } \\
\text { cyme, on stem } \\
\text { below/above } \\
\text { leaf }\end{array}$ & $\begin{array}{l}\text { solitary, on } \\
\text { stem above/ } \\
\text { below leaf }\end{array}$ & cyme & cyme & cyme \\
\hline $\begin{array}{l}\text { Pedicel at } \\
\text { fruiting }(\mathrm{mm})\end{array}$ & $1.5-3$ & $4.6-8.4$ & $2.3-3.7$ & $2.5-2.9$ & $3.6-4.3$ & $2.6-3$ \\
\hline $\begin{array}{l}\text { Corolla } \\
\text { diameter }(\mathrm{mm})\end{array}$ & $3.7-4$ & $5-8$ & 3 & $3.8-4.8$ & $9-10$ & $3.2-4.6$ \\
\hline $\begin{array}{l}\text { Position of } \\
\text { anthers }\end{array}$ & $\begin{array}{l}\text { within corolla } \\
\text { tube }\end{array}$ & $\begin{array}{l}\text { outside corolla } \\
\text { tube }\end{array}$ & $\begin{array}{l}\text { within corolla } \\
\text { tube }\end{array}$ & $\begin{array}{l}\text { within corolla } \\
\text { tube }\end{array}$ & $\begin{array}{l}\text { outside } \\
\text { corolla tube }\end{array}$ & $\begin{array}{l}\text { within } \\
\text { corolla } \\
\text { tube }\end{array}$ \\
\hline $\begin{array}{l}\text { Fruiting calyx } \\
(\mathrm{mm})\end{array}$ & $2.3-3$ & $3.5-4.2$ & $2.1-2.7$ & $2.7-2.8$ & $3.9-4.4$ & $4.5-5$ \\
\hline Nutlet shape & ovoid-ellipsoid & ovoid-ellipsoid & ovoid & $\begin{array}{l}\text { ovoid- } \\
\text { ellipsoid }\end{array}$ & ovoid & ovoid \\
\hline $\begin{array}{l}\text { Nutlet size } \\
(\mathrm{mm})\end{array}$ & $1.2 \times 0.7-0.8$ & $\begin{array}{l}1.2-1.8 \times 0.8 \\
-1.2\end{array}$ & $\begin{array}{l}1-1.3 \times 0.6 \\
-1\end{array}$ & $\begin{array}{l}1.4-1.5 \times \\
0.7-0.9 \\
\end{array}$ & $\begin{array}{l}1.7-1.9 \\
\times 1.1 \\
\end{array}$ & $\begin{array}{l}1.2-1.8 \times \\
0.9-1.1 \\
\end{array}$ \\
\hline $\begin{array}{l}\text { Known } \\
\text { distribution }\end{array}$ & South Island & North Island & $\begin{array}{l}\text { North \& } \\
\text { South Island }\end{array}$ & South Island & South Island & $\begin{array}{l}\text { North } \\
\text { \& South } \\
\text { Island }\end{array}$ \\
\hline $\begin{array}{l}\text { Representative } \\
\text { specimen }\end{array}$ & CHR 311719 & \begin{tabular}{|l} 
WELT \\
SP093687
\end{tabular} & \begin{tabular}{|l} 
WELT \\
SP090633
\end{tabular} & $\begin{array}{l}\text { WELT } \\
\text { SP092756 }\end{array}$ & \begin{tabular}{|l} 
WELT \\
SP090249
\end{tabular} & \begin{tabular}{|l} 
WELT \\
SP092226 \\
\end{tabular} \\
\hline
\end{tabular}

Marlborough Conservancy (NM) and the Museum of New Zealand Te Papa Tongarewa (WELT) were checked for previous collections of these two entities. Type material of known Myosotis species stored at the Auckland Museum (http://www.aucklandmuseum.com/57/botany) and Museum of New Zealand (http://collections.tepapa.govt. 
nz/search.aspx?term=Myosotis types) were also studied and compared with the new material collected at Kahurangi National Park.

\section{Taxonomy}

Myosotis chaffeyorum C.A.Lehnebach, sp. nov. urn:Isid:ipni.org:names:77121627-1

http://species-id.net/wiki/Myosotis_chaffeyorum

Figs $1-2$

Diagnosis. Similar to M. spathulata and M. matthewsii, but differs from Myosotis spathulata by its well-defined, slender petiole; appressed, straight hairs on stem, petiole, leaf lamina and margin; and its decumbent stem not rooting at nodes. It differs from M. matthewsii by its strigose indumentum on leaf upper surface; smaller flowers (3.7 $-4 \mathrm{~mm}$ across vs $5-8 \mathrm{~mm}$ across); stamens included in the corolla tube and fruiting calyx on shorter pedicel $(1.5-3 \mathrm{~mm}$ vs $4.6-8.4 \mathrm{~mm})$.

Type. NEW ZEALAND. South Island, north-west Nelson: Takaka Valley, under overhanging limestone rock in forest, alt. ca 730 m, February 1977, A.P.Druce s.n. (Holotype: CHR [CHR 311719]; Fig. 1).

Plant perennial, $1.4-4.6 \mathrm{~cm}$ tall. Rosette leaves $6-9$, lamina orbicular, $8.1-8.9$ $\times 7.7-9.2 \mathrm{~mm}$, apex mucronate, mucro ca $1 \mathrm{~mm}$ long. Leaf indumentum strigose, hairs on upper and lower surface sparsely distributed, non overlapping, appressed and antrorse. Hairs on leaf margin appressed. Petiole well-defined, $11.9-13.5 \times 0.2-0.3$ $\mathrm{mm}$; hairs appressed, antrorse, sparsely distributed. Stem light brown, decumbent, not rooting at nodes, $59-100 \times 0.3-0.5 \mathrm{~mm}$. Stem hairs appressed as for leaves, hairs 0.2 $-0.6 \mathrm{~mm}$ long. Stem leaves elliptic or orbicular, $7.2-8.8 \times 4.4-6.2 \mathrm{~mm}$, mucronulate, shortly petiolate or sessile towards distal end of stem. Indumentum as for rosette leaves. Calyx lobes lanceolate, $1.5-2 \mathrm{~mm}$ long, hairs in upper half of the lobe only. Fruiting calyx $2.3-3 \mathrm{~mm}$ long; hairs appressed, straight, overlapping, not uniform in size. Flowers borne along the trailing stem, each usually opposite to a leaf. Pedicel at fruiting $1.5-3 \mathrm{~mm}$ long. Corolla white with yellow scales, $3.7-4 \mathrm{~mm}$ across. Corolla lobes obovate, not overlapping, $1.4-1.8 \times 1.2-1.6 \mathrm{~mm}$, apex rounded or irregularly notched. Corolla tube $2-2.2 \mathrm{~mm}$ long. Stamens included in the corolla, with only the anther's appendage slightly above the scales. Filament attached below scales. Anther $0.5 \times 0.2 \mathrm{~mm}$. Style $1.8 \mathrm{~mm}$ long, stigma clavate. Nutlet smooth, light brown, ovoid to ellipsoid, $1.2 \times 0.7-0.8 \mathrm{~mm}$, ventral surface rounded.

Specimens examined. New Zealand, South Island: north-west Nelson. Kahurangi National Park, upper Takaka River track, under overhang of limestone outcrop, alt. 857 m, 8 January 2011, C.A.Lehnebach \& A.Zeller s.n. (WELT SP092173). Track along Takaka River, under overhang of limestone, alt. 736 m, 8 January 2011, C.A.Lehnebach \& A.Zeller s.n. (WELT SP092172). Takaka Valley, alt. 900 m, under overhanging limestone rock in forest, February 1977, A.P. Druce s.n. (CHR 311720). 


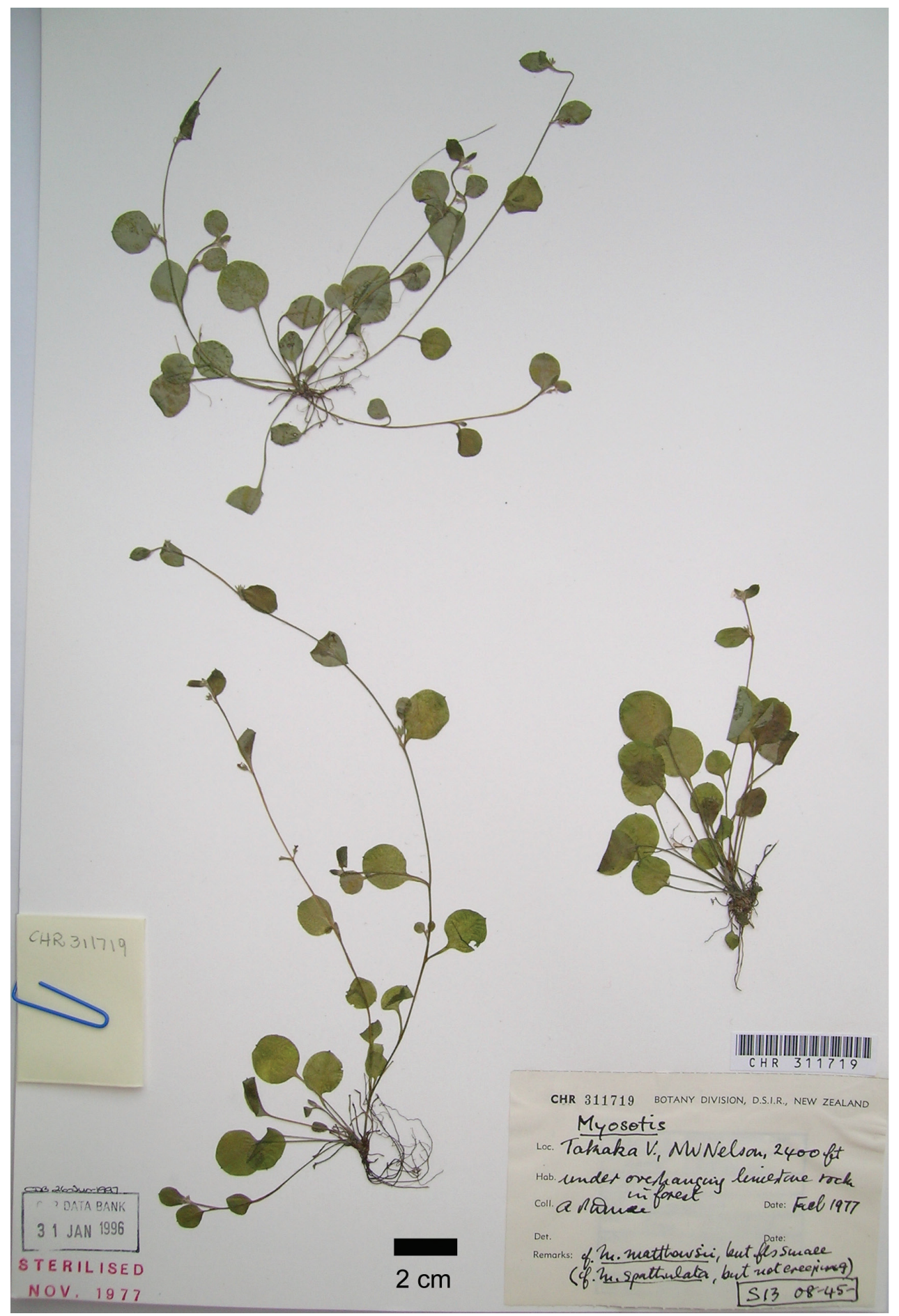

Figure I. Photograph of the holotype of Myosotis chaffeyorum C.A. Lehnebach. (A.P.Druce s.n., CHR 311719). Copyright Allan Herbarium (CHR), Landcare Research. New Zealand. 


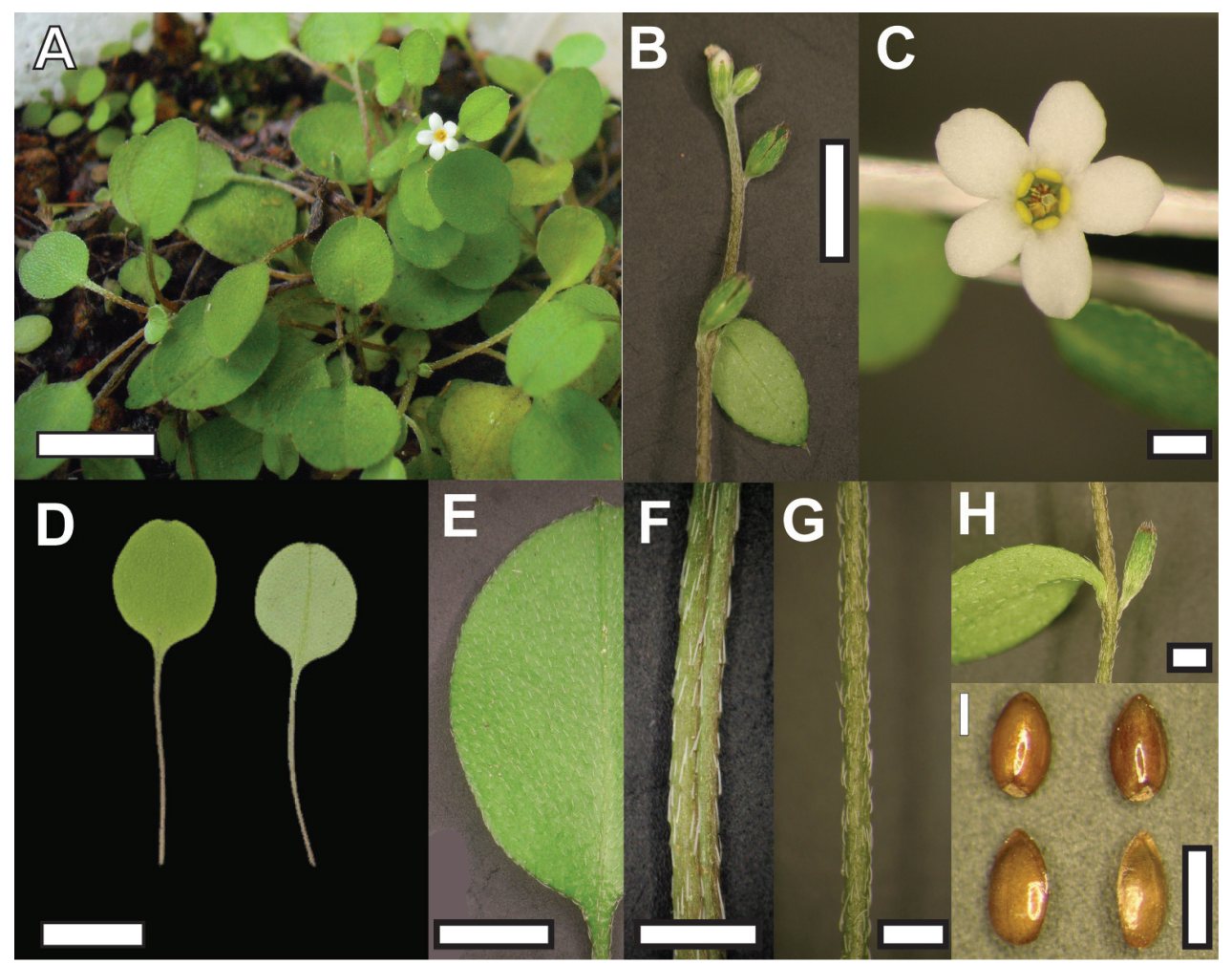

Figure 2. Plant of Myosotis chaffeyorum (A) and close-up view of vegetative and reproductive structures (B Flowering stem C Flower D Rosette leaves E Rosette leaf indumentum $\mathbf{F}$ Petiole $\mathbf{G}$ Stem $\mathbf{H}$ Node with flower and stem leaf I Nutlets). Bar $=1 \mathrm{~cm}$ in A \& D, $5 \mathrm{~mm}$ in B \& E, $1 \mathrm{~mm}$ in C, F, G, H, I. Material from WELT SP092173 (D, E, F, G, H ) and WELT SP094151 (A, B, C, I).

Takaka River, near Ghost Creek Saddle, alt. 840 m, under overhang of limestone outcrop on dry loose fine soil, 22 April 2005, S. Courtney s.n. (NM 2688). Takaka Valley, Paynes Ford, at a base of limestone bluff, 30 October 2010, S. Courtney s.n. (NM 4835). Aniseed Valley. Valley down which Roding River, tributary of the Wairoa River, runs, 26 November 1967, R.H.S. (CHR 269160).

Etymology. This species is named after Annie and Henry Chaffey (http://www. teara.govt.nz/en/biographies/4c15/1), who lived from ca 1913, for almost 40 years, as self-sustained, pioneers/exiles in this mountainous area of Kahurangi National Park. The tiny cottage they lived in still remains in place and served me as shelter during the expedition in which this new species was collected.

Distribution. Endemic to New Zealand, only found in north-west Nelson (South Island). Detailed geographic coordinates are not shown to protect this species from illegal collection but are available from the author on request.

Conservation status. Currently the existence of only five populations of this species can be confirmed. Two of them are within Kahurangi National Park where they occupy an approximate area of $6 \mathrm{~m}^{2}$ and $1 \mathrm{~m}^{2}$. The number of individuals at each site is 
low, ca 20 and 3, respectively. Three other populations are found outside the park, two of them in smaller protected areas which are regularly monitored by the Department of Conservation. At all these sites the species occupies a similar habitat and a small area (Shannel Courtney, personal communication). Considering this information and following the New Zealand Threat Classification System (Townsend et al. 2008), M. chaffeyorum should be considered as "Nationally Critical".

Ecology. This is a perennial, self-pollinating species. It is habitat-specific and restricted to dry loose fine soil under shelters formed by limestone overhangs.

Discussion. The earliest known collection of $M$. chaffeyorum dates from 1967 (CHR 269160). Its distinctiveness from other species of Myosotis, however, was only noticed ca 10 years later when Anthony (Tony) Druce collected it while surveying the flora associated with Palaeogene calcareous rocks in north-west Nelson (Druce, unpublished). Druce noticed the overall similarity of this species to $M$. matthewsii and M. spathulata but also differences between them, which he wrote on the labels of the herbarium sheets of these collections (see Fig. 1). These notes read "cf. M. matthewsii, but the flowers are smaller" and "cf. M. spathulata, but stem not creeping".

Myosotis matthewsii and M. spathulata are the only forget-me-nots in New Zealand with orbicular rosette leaves with which $M$. chaffeyorum could be confused. The small flower with stamens within the corolla tube, the absence of roots at the nodes of the decumbent flowering stem and the strigose indumentum of the leaf lamina, petiole and stems of $M$. chaffeyorum are key diagnostic characters to distinguish it from $M$. matthewsii or M. spathulata. In the absence of flowers, $M$. matthewsii can be distinguished from $M$. chaffeyorum by the presence of arcuate and erect hairs on the upper surface of the rosette leaves, larger leaves and a longer pedicel at fruiting (see Table 1). As for M. spathulata, if no stems are present, it can be readily distinguished from $M$. chaffeyorum by the hispid indumentum on the leaf petiole and larger leaf lamina (see Table 1).

\section{Myosotis mooreana C.A.Lehnebach, sp. nov.}

urn:Isid:ipni.org:names:77121628-1

http://species-id.net/wiki/Myosotis_mooreana

Figs 3-4

Diagnosis. Similar to $M$. forsteri and $M$. brockiei, but differs from $M$. forsteri by its obovate rosette leaves; larger leaves at base of the cyme and smaller calyx at fruiting. It differs from $M$. brockiei by its smaller flowers $(3.8-4.8 \mathrm{~mm}$ vs $9-10 \mathrm{~mm})$; stamens included within the corolla tube; fruiting calyx with shorter pedicel $(2.5-2.9 \mathrm{~mm}$ vs $3.6-4.3 \mathrm{~mm}$ ); and hispid indumentum on leaves and petiole.

Type. NEW ZEALAND. South Island, north-west Nelson: Kahurangi National Park, Cobb Reservoir, among leaf litter accumulated by the side of large boulders in forest, alt. ca 867 m, 6 January 2011, C.A.Lehnebach \& A.Zeller s.n. (Holotype: WELT [WELT SP092756/A]; Fig. 3). 


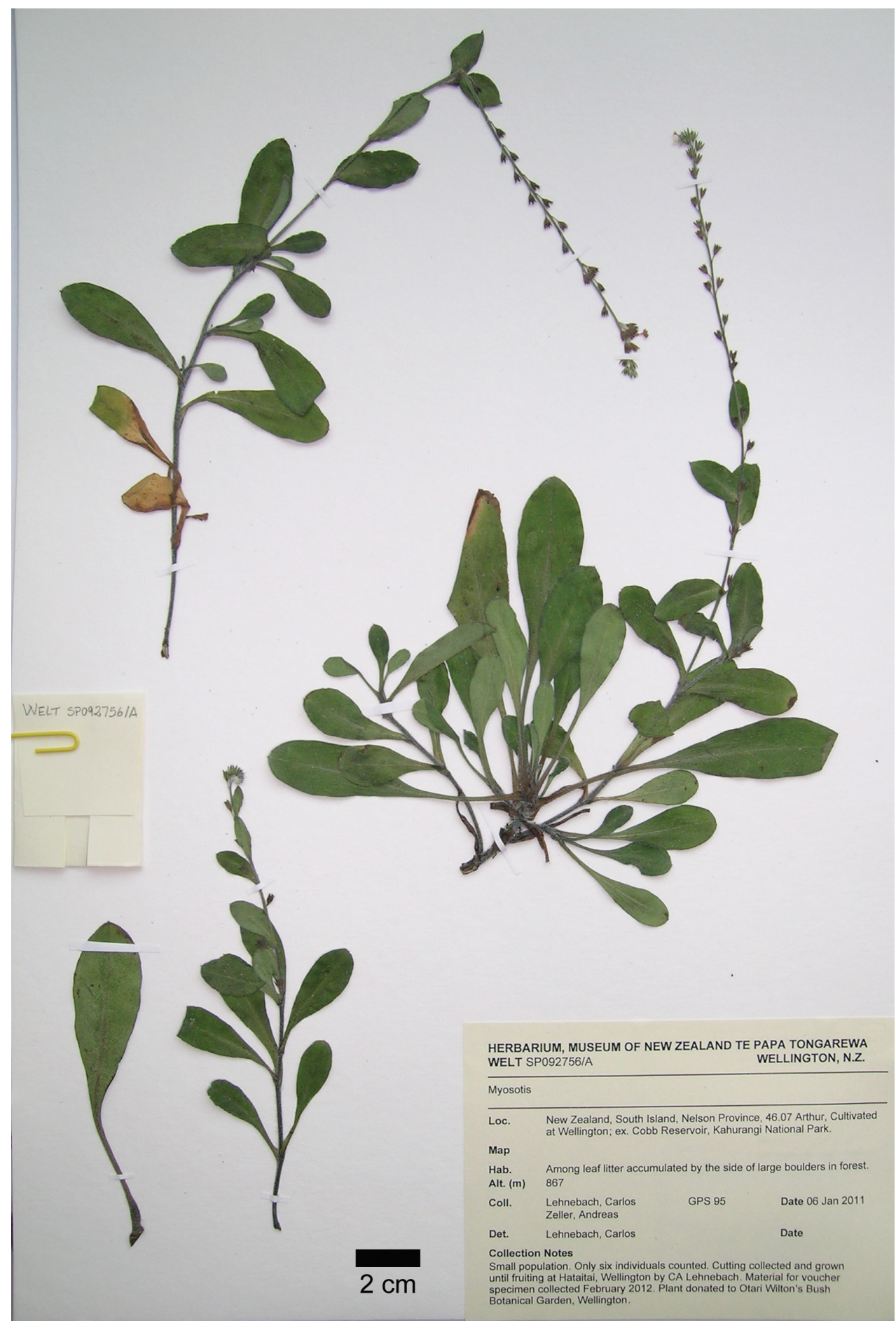

Figure 3. Photograph of the holotype of Myosotis mooreana C.A. Lehnebach. (C.A.Lehnebach \& A.Zeller s.n., WELT SP092756/A). 


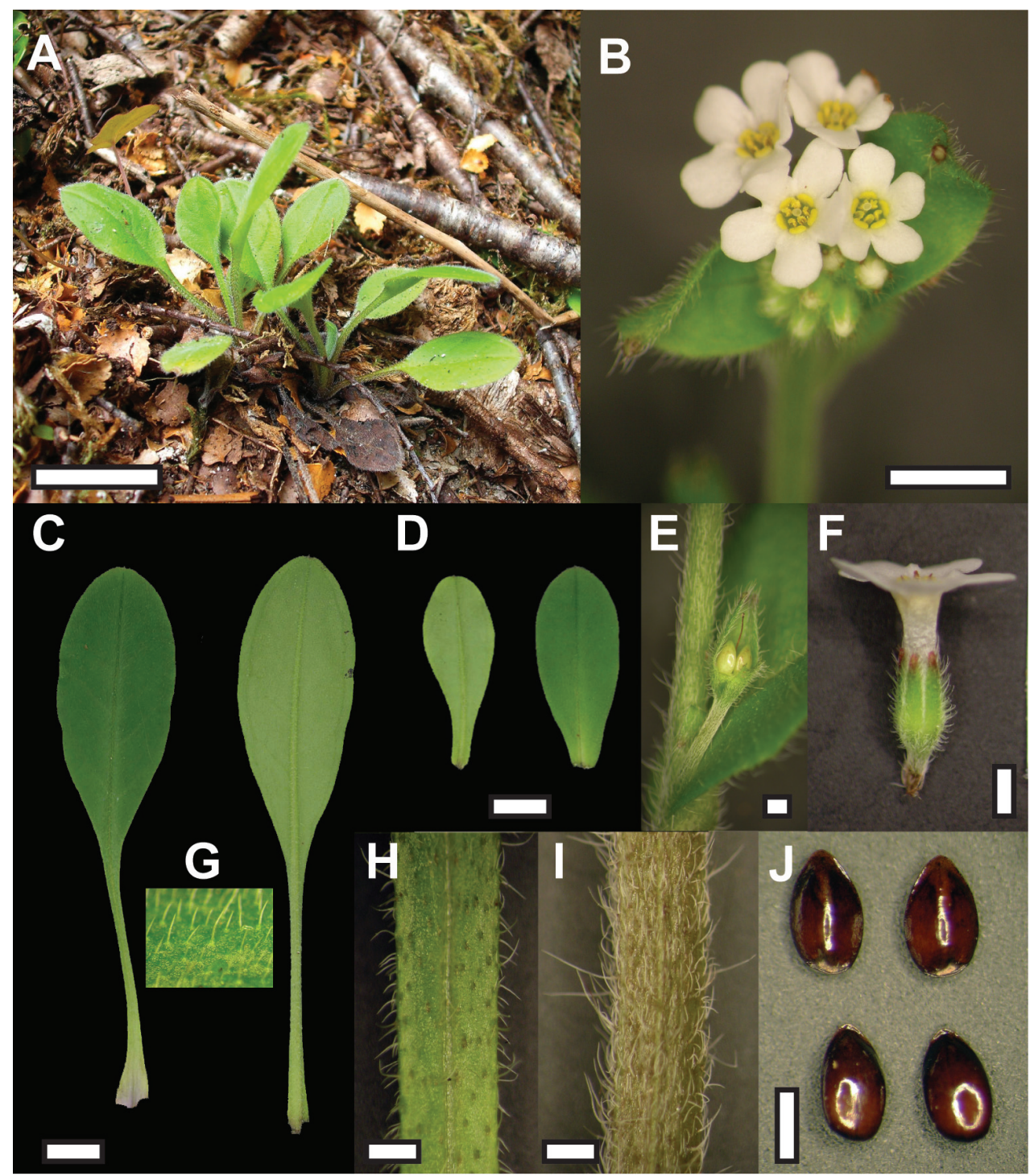

Figure 4. Plant of Myosotis mooreana in situ $(\mathbf{A})$ and close-up view of vegetative and reproductive structures (B Inflorescence C Rosette leaves D Stem leaves E Fertilised flower at leaf axil F Flower $\mathbf{G}$ Rosette leaf indumentum, upper surface $\mathbf{H}$ Rosette leaf petiole I Stem J Nutlets). Bar = $1 \mathrm{~cm}$ in A, C \& D, $5 \mathrm{~mm}$ in B, $1 \mathrm{~mm}$ in E, F, H, I, J. Material from WELT SP092756/A.

Plant perennial, ca $20 \mathrm{~cm}$ tall. Rosette leaves 5 - 12, obovate, $32.4-56 \times 15.8-$ $20.5 \mathrm{~mm}$; apex mucronulate, ca $0.4 \mathrm{~mm}$ long. Leaf lamina base attenuate to petiole. Leaf indumentum hispid, hairs on upper surface sparsely distributed, antrorse, arcuate or erect. Hairs on the lower surface sparsely distributed, retrorse, arcuate or erect. Hairs arcuate or straight on margin. Petiole $26-40 \times 1.4-1.8 \mathrm{~mm}$, hispid, hairs erect, arcuate, antrorse or retrorse on margins. Flowering stem ascending, dark green to brown, 
$210 \times 1.5-1.9 \mathrm{~mm}$. Hairs, appressed, arcuate or erect, $0.8-2.1 \mathrm{~mm}$ long. Stem leaves elliptic-obovate, mucronulate, $15.3-35.4 \times 6.4-14 \mathrm{~mm}$, either shortly petiolate or sessile towards distal end of the inflorescence. Indumentum as for rosette leaves. Cyme with $15-31$ flowers. Pedicel at fruiting, $2.5-2.9 \mathrm{~mm}$. Calyx lobes lanceolate, $2.3-2.8$ $\mathrm{mm}$ long, hairs inside calyx in upper half or along entire lobe. Fruiting calyx $2.7-2.8$ $\mathrm{mm}$ long, hairs densely distributed, overlapping and hooked or straight. Corolla white with yellow scales, $3.8-4.8 \mathrm{~mm}$ across, lobes ovate, $2 \times 1.6-1.8 \mathrm{~mm}$; not overlapping, apex rounded or irregularly notched. Corolla tube $3 \mathrm{~mm}$ long. Stamens included within the corolla tube, with only the anther's appendage above the scales. Filament attached below the scales. Anther $0.8 \times 0.2 \mathrm{~mm}$. Style $3 \mathrm{~mm}$ long, stigma clavate. Nutlet smooth, dark brown, ovoid to ellipsoid, $1.4-1.5 \times 0.7-0.9 \mathrm{~mm}$, ventral surface keeled.

Etymology. This species is named in honour of Lucy Beatrice Moore, New Zealand botanist (http://www.teara.govt.nz/en/biographies/5m55/1) who described several species of endemic Myosotis and revised this genus for the Flora of New Zealand (Allan 1961).

Distribution. Endemic to New Zealand. Known from a single location in Kahurangi National Park, north-west Nelson (South Island). Detailed geographic coordinates are not shown to protect this species from illegal collection but are available from the author on request. It is likely $M$. mooreana also occurs at two other sites within the Park (Shannel Courtney, personal communication) but this cannot be confirmed at this stage.

Conservation status. Considering the small population size for this species (six individuals only), low number of mature individuals observed in the population and the small area of occupancy (less than $1 \mathrm{~m}^{2}$ ), and following the New Zealand Threat Classification System (Townsend et al. 2008), M. mooreana should be rated as "Nationally Critical".

Ecology. This is a perennial, fertile, self-pollinating species. It grows among the twigs and leaf-litter accumulated among large boulders under red beech (Nothofagus fusca) forest.

Discussion. There are only two species of forget-me-nots in New Zealand that can be mistaken with $M$. mooreana; i.e. $M$. brockiei and $M$. forsteri. These two are the only species growing in a similar habitat, under forest or scrub in north-west Nelson and throughout New Zealand, respectively. The main differences between $M$. mooreana and $M$. brockiei are the large flowers with stamens fully exserted beyond the corolla tube in the latter species. Flowers in $M$. mooreana are only ca $5 \mathrm{~mm}$ across and stamens are always included within the corolla tube. In contrast, $M$. brockiei bears flowers ca 1 $\mathrm{cm}$ across and anthers with long filaments (ca $4 \mathrm{~mm}$ ). When not fertile, indumentum and leaf shape are useful characters to distinguish between these two species. Myosotis mooreana bears oblanceolate rosette leaves and wide cauline leaves covered by a combination of arcuate, erect, antrorse and retrose hairs. Myosotis brockiei, in contrast, has narrowly elliptic leaves with a distinct tomentose almost greyish indumentum. Leaf shape is the most useful character to differentiate $M$. mooreana from $M$. forsteri. The latter species possess orbicular to broadly elliptic leaves with a well-defined petiole. The 
flowers of both species are very similar in size (see Table 1) but the calyx of $M$. forsteri at fruiting is almost twice the size of the fruiting calyx of $M$. mooreana.

\section{Key to Myosotis chaffeyorum, M. mooreana and other white flowered and laxly tufted species of Myosotis found in forest areas of New Zealand}

1 Rosette leaf lamina obovate to narrowly elliptic ................................2

- $\quad$ Rosette leaf lamina orbicular to broadly elliptic.................................... 3

2 Leaf and petiole indumentum tomentose; stem erect; calyx $3.9-4.4 \mathrm{~mm}$ at fruiting; stamens fully exserted from corolla tube

M. brockiei

- $\quad$ Leaf and petiole indumentum hispid; stem ascending; calyx ca $2.8 \mathrm{~mm}$ at fruiting; stamens included in corolla tube

M. mooreana

3 Petiole of rosette leaves 1.9 - $3 \mathrm{~mm}$ wide; stem ascending; cyme well-defined; calyx ca $5 \mathrm{~mm}$ long at fruiting

M. forsteri

- $\quad$ Petiole of rosette leaves 0.2 - $0.6 \mathrm{~mm}$ wide; stem prostrate; cyme ill-defined; calyx $<4.5 \mathrm{~mm}$ at fruiting .................................................... 4

4 Indumentum on leaf margin, petiole and stem hispid; stem creeping, rooting at nodes M. spatbulata

- Indumentum on leaf margin, petiole and stem strigose; stem decumbent, no roots at the nodes.

5 Indumentum on leaf surface hispid; pedicel $4.6-8.4 \mathrm{~mm}$ long at fruiting; calyx hairs arcuate; stamens fully exserted from corolla tube....M. matthewsii Indumentum on leaf surface strigose; pedicel $1.5-3 \mathrm{~mm}$ long at fruiting; calyx hairs straight; stamens included in corolla tube

M. chaffeyorum

\section{Acknowledgments}

I would like to thank Andreas Zeller and Barry Sneddon for their help in the field, Andrea Brandon and Shannel Courtney for sharing their knowledge on Myosotis in the Kahurangi National Park, the staff of AK, CHR and WELT for their assistance with loans, and Patrick Brownsey, Phil Garnock-Jones and Barry Sneddon and two anonymous reviewers for comments on an earlier version of this manuscript and Phil Garnock-Jones for advice on Latin names. This research was supported by the New Zealand Ministry of Science and Innovation through the Defining New Zealand's Land Biota Programme.

\section{References}

Allan HH (1961) Flora of New Zealand. Vol. I. Wellington: Government Printer. liv + 1885 http://floraseries.landcareresearch.co.nz/pages/Index.aspx 
Brandon A (2001) Breeding systems and rarity in New Zealand Myosotis. PhD Thesis, Massey University, Palmerston North. New Zealand.

Breitwieser I, Brownsey P, Garnock-Jones P, Perrie L, Wilton A (2012) In: Gordon D (Ed) New Zealand inventory of biodiversity. Phylum Tracheophyta, vascular plants. Vol. 3. Kingdoms Bacteria, Protozoa, Chromista, Plantae, Fungi. Canterbury University Press, 411-459.

Druce A (unpublished) Plant checklist for Tertiary calcareous areas, NW Nelson. http://www. nzpcn.org.nz

Moore LB (1961) Myosotis. In: Allan HH (Ed) Flora of New Zealand. Vol. I. Wellington: Government Printer, 807-833.

Moore LB (1988) Myosotis. In: Webb CJ, Sykes WR, Garnock-Jones PJ (Eds) Flora of New Zealand. Vol. IV. Naturalised pteridophytes, gymnosperms, dicotyledons. Botany Division, DSIR. Christchurch, 377-390.

Moore LB, Simpson MJ (1973) A new Myosotis from north-west Nelson. New Zealand Journal of Botany11: 163-170. doi: 10.1080/0028825X.1973.10430270

Townsend A, de Lange P, Duffy C, Miskelly C, Molloy J, Norton D (2008) New Zealand Threat Classification System Manual. Science \& Technical Publishing, Department of Conservation. New Zealand.

Weigend M, Gottschling M, Selvi F, Hilger HH (2010) Fossil and extant Western Hemisphere Boragineae, and the polyphyly of "Trigonotideae" Riedl (Boraginaceae: Boraginoideae). Systematic Botany 35: 409-419. doi: 10.1600/036364410791638423

Winkworth RC, Grau J, Robertson AW, Lockhart PJ (2002) The origins and evolution of the genus Myosotis L. (Boraginaceae). Molecular Phylogenetics and Evolution 24: 180-193. doi: 10.1016/S1055-7903(02)00210-5

\section{Appendix I}

Representative material listed in Table 1.

Myosotis brockiei: New Zealand. South Island: north-west Nelson, Kahurangi National Park, base of the cliff behind Growler Rock Shelter, alt. 1003 m, 4 January 2011, C.A. Lehnebach \& A.Zeller s.n. (WELT SP090249).

Myosotis forsteri: New Zealand, North Island: Pureora Forest Park, Whenuakura, January 2011, T.Emmitt s.n. (WELT SP092226).

Myosotis matthewsii: New Zealand, North Island: Warawara Forest, 8 March 2012, J.Prebble et al. JMP12-010g (WELT SP093687).

Myosotis spathulata: New Zealand, North Island: Waipuna Station, south end of Te Waka Range, alt. 835 m, 13 December 2011, H.Meudt et al. HMM 334 A (WELT SP090633). 